\title{
Hyperglycemic Effect of Pyruvic Acid Phenylhydrazone
}

\author{
U. BONOMI \\ Medical Research and Clinical Investigation Laboratories - Lepetit S.p.A. Milan (Italy) \\ (Director: Prof. F.M. ChIANCONE) \\ Received January 17, 1966
}

Summary. Pyruvic acid-phenylhydrazone has been shown, by injection into rats, to increase the blood sugar level. Hyperglycaemia started $30 \mathrm{~min}$ and ceased $330 \mathrm{~min}$ after the injection. This activity of the compound was counteracted by insulin and by tolbutamide. Adrenalectomized rats failed to show any significant increase in blood sugar after the injection of the compound.

L'effet hyperglycémiant de la phénylhydrazone de l'acide pyruvique

Résumé. La phénylhydrazone de l'acide pyruvique, injectée chez le rat, a un effet hyperglycémiant qui débute à la 30 ème minute et se termine 330 minutes après l'injection. Cette action est atténuée par l'insuline et le tolbutamide. Les rats surrénalectomisés ne présentent pas d'élévation significative de la glycémie après l'injection de cette substance.

Blutzuckersteigerung durch Brenztraubensäure-Phenylhydrazon

Zusammenfassung. Es konnte gezeigt werden, daß die Injektion von Brenztraubensäure-Phenylhydrazon bei Ratten zu einer Erhöhung des Blutzuckerspiegels führt. Die Hyperglykämie begann 30 Minuten und endete 330 Minuten nach der Injektion. Die Wirkung der Substanz wurde durch Insulin und Tolbutamid gehemmt. Adrenalektomierte Ratten wiesen nach Verabreichung der Substanz keinen signifikanten Blutzuckeranstieg auf.

Key-words: Pyruvic acid phenylhydrazone, blood glucose, insulin, tolbutamide, adrenalectomy.
During investigations carried out at our laboratory on the relationships between experimental diabetes and tryptophan, an increase in blood sugar levels was noticed in rats injected with phenylhydrazones of ketoacids. The hyperglycemic effect was more evident in normally fed than in starved animals, and was counteracted by insulin and tolbutamide.

The present paper discusses the effect of pyruvie acid phenylhydrazone on the blood sugar level of rats in various experimental conditions.

\section{Material and Methods}

Pyruvic acid phenylhydrazone (PPH) was prepared by mixing pyruvic acid and phenylhydrazine hydrochloride according to the method of FiscHer [1]. The compound was recrystallized twice from ethanol; its melting point was $192^{\circ}$. A $3 \%$ solution of PPH in water was prepared by adjustment to $\mathrm{pH}$ 7.8-8.0 with $\mathrm{NaOH}$; the solution was used immediately.

Male and female Wistar rats, weighing $300-350 \mathrm{~g}$, were used either in the fed or the fasted state. PPH was injected by the intraperitoneal or the intravenous route at doses varying from 450 to $550 \mathrm{mg} / \mathrm{kg}$ in two injections at $15 \mathrm{~min}$ interval. Glucose $(800 \mathrm{mg} / \mathrm{kg})$ was given orally between the two injections of PPH.

Insulin (Lilly) was injected subcutaneously ( 0.3 or 1.0 I.U. per animal) immediately after the first PPH injection. Tolbutamide $(200-300 \mathrm{mg} / \mathrm{kg})$ was given orally, 15 or $90 \mathrm{~min}$ before PPH; the rats of this group were given a dose of $500 \mathrm{mg} / \mathrm{kg}$ PPH.

Blood sugar curves were determined by collecting blood samples from the tail vein at $0,30,90,150,210$, 330 min after the second PPH injection. Glucose was estimated with the Somogri-NeLson method [5, 8].
PPH was observed to react with the arsenomolybdate reagent of NELSON. In order to ascertain whether the reducing power in the blood of PPH-treated rats was actually due to glucose, blood samples from these animals were deproteinized with the Somogyi reagent and the clear filtrate pretreated for 3 hours at $38^{\circ}$ with glucose-oxidase before adding the Nelson reagent; in this way the glucose was removed, allowing the estimation of the residual reducing power of blood [10]. A large portion, more than 90 percent, of the reducing power of the blood after PPH injection appeared to be actually due to true glucose, and less than 10 percent to PPH.

In some cases, liver glycogen was isolated by precipitation with ethanol from tissue hydrolysates in $30 \%$ potassium hydroxide, the precipitate being washed thoroughly with ethanol and hydrolyzed with $1 \mathrm{~N}$ sulphuric acid; glycogen was estimated by measuring the reducing power of the sulphuric acid-hydrolyzate.

Some experiments were performed on adrenalectomized rats. Animals were operated and for the subsequent 8 days given the normal diet together with $0.9 \%$ solution of sodium chloride; they were then treated with PPH and glucose, and the blood sugar curve determined as for the normal animals. Another group of rats was operated, and for the subsequent 6 days given a high protein diet ( $25 \%$ protein) together with $0.9 \%$ solution of sodium chloride; each rat then received $2 \mathrm{mg}$ hydrocortisone, dissolved in $10 \%$ ethanol and given in 4 intramuscular injections over a period of 3 hours. The animals were then submitted to the treatment with PPH and glucose. 


\section{Results}

PPH was well tolerated by all the rats. Slight traces of haemolysis were observed $5 \frac{1}{2}$ hours after the injection. crease started $30 \mathrm{~min}$ and lasted over $210 \mathrm{~min}$ after PPH injection.

At the same time, the liver glycogen content decreased markedly, from an average of $4.97 \pm 0.66$

Table 1. Blood glucose of normally fed or starved rats treated with $P P H^{1}$ or $P P H^{1}$ and glucose

\begin{tabular}{|c|c|c|c|c|}
\hline \multirow{2}{*}{$\begin{array}{l}\text { Time after } \\
\text { PPH injection }\end{array}$} & \multicolumn{2}{|l|}{ Fed rats } & \multicolumn{2}{|l|}{ Starved rats } \\
\hline & $\mathrm{PPH}^{3}$ & $\mathrm{PPH}+$ glucose $^{3}$ & $\mathrm{PPH}^{3}$ & $\mathrm{PPH}+$ glueose $^{3}$ \\
\hline Basal & $0.96 \pm 0.05(4)$ & $0.88 \pm 0.16(4)$ & $0.64 \pm 0.06(4)$ & $0.73 \neq 0.08(4)$ \\
\hline $30 \mathrm{~min}$ & $2.34 \pm 0.38(4)$ & $2.28 \pm 0.18(4)$ & $1.08 \pm 0.08(4)$ & $1.82 \pm 0.13(4)$ \\
\hline $90 \mathrm{~min}$ & $2.69 \mp 0.47(4)$ & $2.84 \pm 0.21(4)$ & $1.42 \pm 0.24(4)$ & $2.29 \pm 0.37(4)$ \\
\hline $150 \mathrm{~min}$ & $1.87 \pm 0.43(4)$ & $2.29 \pm 0.29(4)$ & $1.62 \pm 0.16(4)$ & $2.57 \pm 0.23(4)$ \\
\hline $210 \mathrm{~min}$ & $1.52 \mp 0.31(4)$ & $1.97 \pm 0.28(4)$ & $1.47 \pm 0.20(4)$ & $2.07 \pm 0.17(4)$ \\
\hline $330 \mathrm{~min}$ & $0.78 \pm 0.05(4)$ & $1.24 \pm 0.15(4)$ & $0.91 \pm 0.28(4)$ & $0.98 \pm 0.31(4)$ \\
\hline
\end{tabular}

$1 \mathrm{PPH} 550 \mathrm{mg} / \mathrm{kg}$ intraperitoneally.

2 glucose $800 \mathrm{mg} /$ per animal orally.

3 Data for each group expressed as the mean of the blood glucose ( $\mathrm{mg} / \mathrm{ml}$ of blood) $\pm \mathrm{stan}$ dard deviation, with the number of rats in parentheses.

Table 2. Insulin effect on blood glucose of starved rats treated with $P P H^{1}$ and glucose ${ }^{2}$

\begin{tabular}{cll}
\hline $\begin{array}{l}\text { Time after } \\
\text { PPH injection }\end{array}$ & PPH +glucose & $\begin{array}{l}\text { PPH +glucose } \\
\text { tinsulin }^{3}\end{array}$ \\
\hline Basal & $0.73 \pm 0.08(4)$ & $0.67 \pm 0.09(4)$ \\
$30 \mathrm{~min}$ & $1.82 \pm 0.13(4)$ & $0.80 \pm 0.16(4)$ \\
$90 \mathrm{~min}$ & $2.29 \pm 0.37(4)$ & $0.80 \pm 0.23(4)$ \\
$150 \mathrm{~min}$ & $2.57 \pm 0.23(4)$ & $0.93 \pm 0.28(4)$ \\
$210 \mathrm{~min}$ & $2.07 \pm 0.17(4)$ & $1.17 \pm 0.34(4)$ \\
$330 \mathrm{~min}$ & $0.98 \pm 0.31(4)$ & $1.15 \pm 0.44(4)$ \\
\hline
\end{tabular}

1 PPH: $550 \mathrm{mg} / \mathrm{kg}$ intraperitoneally.

${ }^{2}$ glucose: $800 \mathrm{mg}$ per animal orally.

3 insulin: $0.3 \mathrm{I}$. U. per animal subcutaneously.

4 Data for each group expressed as the mean of the blood glucose $(\mathrm{mg} / \mathrm{ml}$ of blood) \pm standard deviation, with the number of rats in parentheses. (mean \pm S.D.) per cent fresh weight to an average of $0.18 \pm 0.12$ per cent 210 min after PPH injection. PPH exerted the same effect by the intravenous as by the intraperitoneal route.

The data given in Table 2 demonstrate that insulin inhibited the hyperglycemic action of PPH. The blood glucose level failed to increase in starved rats treated with glucose, PPH and insulin.

Tolbutamide also reduced the PPH hyperglycemia, as shown by the data of Table 3 . Rats treated with tolbutamide, either 15 or $90 \mathrm{~min}$ before PPH, showed a blood sugar increase less evident than that in the control rats: significant differences were attained only at 210 and 330 min after PPH.

$\mathrm{PPH}$ injected in adrenalectomized rats induced an increase in blood glucose, which was however not sig.

Table 3. Effect of Tolbutamide treatment on blood glucose of starved rats rendered hyperglycemic with $P P H^{1}$ and glucose ${ }^{2}$

\begin{tabular}{|c|c|c|c|c|}
\hline \multirow{2}{*}{$\begin{array}{l}\text { Time after } \\
\text { PPH injection }\end{array}$} & \multicolumn{2}{|c|}{ Tolbutamide $^{3} 15$ min before PPH } & \multicolumn{2}{|c|}{ Tolbutamide ${ }^{3} 90 \mathrm{~min}$ before $\mathrm{PPH}$} \\
\hline & Non-treated ${ }^{4}$ & Treated ${ }^{4}$ & Non-treated ${ }^{4}$ & Treated ${ }^{4}$ \\
\hline Basal & $0.84 \pm 0.11(4)$ & $0.87 \pm 0.03(4)$ & $0.81 \pm 0.10(4)$ & $0.71 \pm 0.09(4)$ \\
\hline $30 \mathrm{~min}$ & $1.75 \pm 0.21(4)$ & $1.52 \pm 0.26(4)$ & $1.84 \pm 0.27(4)$ & $1.50 \pm 0.18(4)$ \\
\hline $90 \mathrm{~min}$ & $2.43 \pm 0.42(4)$ & $2.31 \pm 0.38(4)$ & $2.58 \pm 0.15(4)$ & $2.07 \pm 0.36(4)$ \\
\hline $150 \mathrm{~min}$ & $2.43 \pm 0.30(4)$ & $2.16 \pm 0.36(4)$ & $2.71 \pm 0.67(4)$ & $1.83 \pm 0.12(4)$ \\
\hline $210 \min$ & $2.30 \pm 0.22(4)$ & $1.78 \pm 0.08(4) \mathrm{a}$ & $2.23 \pm 0.34(4)$ & $1.45 \pm 0.12(4) \mathrm{c}$ \\
\hline $330 \mathrm{~min}$ & $1.83 \pm 0.33(4)$ & $1.06 \pm 0.22(4) \mathrm{b}$ & $1.48 \pm 0.21(4)$ & $0.68 \pm 0.15(4) \mathrm{d}$ \\
\hline \multicolumn{5}{|c|}{$\begin{array}{l}1 \text { PPH } 500 \mathrm{mg} / \mathrm{kg} \text { intraperitoneally. } \\
2 \text { glucose } 800 \mathrm{mg} \text { per animal orally. } \\
3 \text { tolbutamide } 300 \mathrm{mg} / \mathrm{kg} \text { orally. } \\
4 \text { Data for each group expressed as the mean of the blood glucose }(\mathrm{mg} / \mathrm{ml} \text { of blood) } \pm \text { stan- } \\
\text { ard deviation, with the number of rats in parentheses. } \\
\text { Significance: } P=0.01-0.001 \text { for a, } \mathrm{b}, \mathrm{c} \text { and } P<0.001 \text { for } \mathrm{d} \text { compared with the corresponding } \\
\text { an-treated group. }\end{array}$} \\
\hline
\end{tabular}

In Table 1 are given the blood sugar levels after intraperitoneal injection of PPH in normally fed and in starved rats, treated or not with glucose orally. PPH induced a definite increase in blood sugar, more evident in normally fed animals treated with glucose. The in- nificant when compared with controls. Data on both group of animals are put together for comparison in Table 4.

Adrenalectomized rats supplemented with a high protein diet and treated with hydrocortisone, in order 
to induce an increase in liver glycogen, did not show any hyperglycemia after PPH injection.

The phenylhydrazone of $\alpha$-ketoglutaric acid was also tested and found to show a lower hyperglycemic activity than PPH.

Table 4. Blood glucose of non-operated or adrenalectomized rats, normally fed and treated with $P P H^{1}$ and glucose ${ }^{2}$

\begin{tabular}{cll}
\hline $\begin{array}{l}\text { Time after } \\
\text { PPH injection }\end{array}$ & Non-operated & \\
& & Operated $^{3}$ \\
\hline Basal & $0.88 \pm 0.16(6)$ & $0.91 \pm 0.03(6)$ \\
$30 \mathrm{~min}$ & $2.28 \pm 0.18(6)$ & $1.54 \pm 0.19(6)$ \\
$90 \mathrm{~min}$ & $2.84 \pm 0.21(6)$ & $\mathbf{1 . 3 4 \pm 0 . 2 5 ( 6 )}$ \\
$\mathbf{1 5 0 \mathrm { min }}$ & $2.29 \pm 0.29(6)$ & $\mathbf{1 . 1 9 \pm 0 . 2 7 ( 6 )}$ \\
$210 \mathrm{~min}$ & $1.96 \pm 0.28(6)$ & $1.03 \pm 0.28(6)$ \\
\hline
\end{tabular}

${ }_{1} \mathrm{PPH} 550 \mathrm{mg} / \mathrm{kg}$ intraperitoneally.

2 glucose $800 \mathrm{mg}$ per animal orally.

3 Data for each group expressed as the mean of the blood glucose $(\mathrm{mg} / \mathrm{ml}$ of blood) \pm standard deviation, with the number of rats in parentheses.

\section{Discussion}

It has been shown in these experiments that pyruvic acid-phenylhydrazone induces a temporary rise of blood sugar levels in rats, lasting a few hours after the injection of the compound. This hyperglycemia due to PPH should be distinguished from permanent hyperglycemias, as for instance those elicited by pancreatectomy or treatment with alloxan. Other compounds have been shown to cause a temporary rise in blood sugar levels: Simon et al. [6, 7] described the hyperglycaemic effect of D-mannoheptulose, and Moloner and CoVAI [4] that of anti-insulin antibodies. Also thiazide diuretics can give hyperglycemia [2, 9].

The similarity of the activity of PPH to that of D-mannoheptulose, as well as the inhibition of PPH hyperglycemia by insulin and by tolbutamide [3], can lead to the assumption that PPH exerts an antagonistic effect on insulin.

That epinephrine can also play a role, is demonstrated by the lack of effect of PPH in adrenalectomized rats. Further experiments are required to elucidate this point.
PPH is active as such; the very slight traces of haemolysis observed $5 \frac{1}{2}$ hours after the injection are probably due to a limited decomposition of PPH into pyruvate and phenylhydrazine.

PPH and the phenylhydrazones of other keto-acids could prove to be useful tools in the screening of hypoglycemic agents.

\section{References}

[1] Fischer, E., und F. Jourdan: Úber die Hydrazine der Brenztraubensäure. Ber. dtsch. chem. Ges. 16, $2241(1883)$.

[2] Goldner, M. G., H. ZARowitz and S. Akgun: Hyperglycemia and glycosuria due to thiazide derivatives administered in diabetes mellitus. New Engl. J. Med. 262, 403 (1960).

[3] Loubatrìnes, A.: Pharmacological actions of the hypoglycaemic arysulphonamides upon the histo. physiology and the physiology of the betacells of the Islets of Langherhans of the pancreas. Proc. 1st Int. Pharmac. Meeting, Stockholm. vol. 1, pag. $47-$ Pergamon Press, 1963.

[4] Moloney, P.J., and M. Coval: Antigenicity of Insulin: Diabetes induced by specific antibodies. Biochem. J. 59, 179 (1955).

[5] NELSON N.: A photometric adaptation of the Somogyi method for the determination of glucose. J. biol. Chem. 153, 375 (1944).

[6] Stmon, E., and P.F. Kraicher: Metabolism of mannoheptulose in the rat. I. Diabetogenic àction. Arch. Biochem. 69, 592 (1957).

[7] - R.O. Scow and S.S. CHERNICK: Effects of Dmannoheptulose and D-sedoheptulose on blood glucose and ketone bodies in the rat. Amer. J. Physiol. 201, 1073 (1961).

[8] Somogyr, M.: Determination of blood sugar. J. biol. Chem. 160, 69 (1945).

[9] WolfF, F.W., R.G. Langdon, B.H. Ruebner, C. Hollander and R.D. Skoglund: An new form of experimental diabetes. Diabetes 12, 335 (1963).

[10] WYagaARden, J.B., S. Segad and J.B. Folex: Physiological disposition and metabolic fate of infused pentoses in man. J. clin. Invest. 36, 1395 (1957).

UMBERTO BONOMT,

Lepetit S.p.A.

Lab. Farmacol. del Metabolismo,

Via Durando, 38, Milano, Italia 